\title{
OPTIMALISASI JARAK TANAM TERHADAP PERTUMBUHAN DAN PRODUKSI BAWANG MERAH (Allium ascalonicum, L) PADA MUSIM PENGHUJAN DI DESA TORONGREJO KECAMATAN JUNREJO KOTA BATU
}

\section{OPTIMIZATION OF PLANTING DISTANCE TO GROWTH AND PRODUCTION OF SHALLOT (Allium ascalonicum, L) AT RAINY SEASON IN TORONGREJO VILLAGE JUNREJO SUBDISTRICT BATU CITY}

\author{
Yustina E.W Lea ${ }^{1}$, Abdul Farid ${ }^{2}$, Arum Pratiwi ${ }^{2}$ \\ ${ }^{1}$ Mahasiswa Politeknik Pembangunan Pertanian Malang \\ ${ }^{2}$ Dosen Politeknik Pembangunan Pertanian Malang
}

\begin{abstract}
ABSTRAK
Rendahnya produksi bawang merah pada musim penghujan yang diakibatkan oleh meningkatnya serangan hama dan penyakit karena kondisi tanah yang terlalu lembab menjadi permasalahan utama yang dihadapi petani saat ini. Tujuan dari kajian ini untuk mengetahui jarak tanam yang optimal terhadap pertumbuhan dan produksi bawang merah (Allium ascalonicum, L) padamusimpenghujandi Desa Torongrejo. Pelaksanaan kajian menggunakan Rancangan Acak Kelompok dengan 4 perlakuan dan 6 ulangan, dilanjutkan dengan uji lanjut DMRT pada taraf $5 \%$. Perlakuan yang diberikan adalah jarak tanam $15 \times 15,20 \times 20,25 \times 25$ dan $30 \times 30 \mathrm{~cm}$ dengan parameter tinggi tanaman, jumlah daun, bobot umbi dan persentase serangan hama penyakit. Hasil kajian menunjukkan bahwa jarak tanam berpengaruh nyata terhadap pertumbuhan dan produksi bawang merah pada musim penghujan dengan jarak paling optimal $20 \times 20 \mathrm{~cm}$.
\end{abstract}

Kata Kunci: Optimalisasi, Jarak Tanam, Bawang Merah

\section{ABSTRACT}

The low production of shallots in the rainy season caused by increasing attacks of pests and diseases due to overly moist soil conditions is a major problem faced by farmers today. The purpose of this study was to find out the optimal plant growth and production of red onions (Allium ascalonicum, L) on rainy season in Torongrejo Village. The study used a Randomized Block Design with 4 treatments and 6 replications, followed by DMRT follow-up at

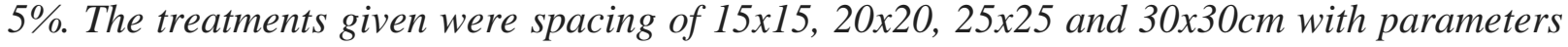
of plant height, number of leaves, tuber weight and percentage of pest attack. The results of the study show that the spacing has a significant effect on the growth and production of shallots in the rainy season with the optimal distance of $20 \times 20 \mathrm{~cm}$.

Keywords: Optimization, Planting Distance, Shallot 


\section{PENDAHULUAN}

\section{Bawang merah (Allium ascalonicum} L.) merupakan salah satu komoditas hortikultura yang startegis dan ekonomis. Menurut BadanL itbang (2006), bawang merah menjadi sumber pendapatan dan kesempatan kerja yang memberikan kontribusi cukup tinggi terhadap perkembangan ekonomi wilayah. Bawang merah dibudidayakan di 24 provinsi dari ujung barat hingga ujung timur Indonesia. Sentra produksi bawang merah di Indonesia adalah Provinsi Jawa Tengah, JawaTimur, Jawa Barat dan Nusa Tenggara Barat (Pusat Data dan Sistem Informasi Pertanian, 2015).

Provinsi Jawa Timur memberikan kontribusi $86,24 \%$ dari total produksi bawang merah Indonesia pada rata-rata produksi tahunan (Pusat Data dan Sistem Informasi Pertanian, 2015).Permintaan yang terus meningkat tiap tahunnya menyebabkan kontribusi yang diberikan belum mencukupi kebutuhan bawang merah dikarenakan produksi yang rendah pada musim penghujan, sehingga mengakibatkan terjadinya fluktuasi produksi dan harga, yang cendrung merugikan petani. Harga bawang merah pada musim penghujan meningkat sebesar Rp 40.000 - 50.000/Kg (BALITSA, 2013).

Kota Batu merupakan salah satu kota penghasil bawang merah untuk wilayah Jawa Timur yang turut mengalami rendahnya produksi bawang merah pada musim penghujan. Menurut Badan Pusat Statistik Kota Batu(2016), selisih produksi bawang merah pada musim kemarau dan musim hujan mencapai 477 kwintal. Hasil identifikasi potensi dan masalah di Desa Torongrejo Kecamatan Junrejo Kota Batu, menunjukan terdapat beberapa permasalahan yang megakibatkan produksi bawang merah rendah pada musim hujan. Permasalahannya antara lain, kurangnya penyinaran matahari, kondisi tanah yang terlalu lembab serta serangan hama dan penyakit yang sangat mempengaruhi pertumbuhan tanaman bawang merah, sehingga produksinya menurun.

Pengaturan jarak tanam menjadi salah satu upaya yang dapat dilakukan untuk meningkatkan produksi bawang merah pada musim penghujan. Pengaturan jarak tanam dengan kerapatan tertentu bertujuan member ruang tumbuh pada tiap-tiap tanaman. Jarak tanam akan mempengaruhi kepadatan dan efisiensi penggunaan cahaya,persaingan diantara tanaman dalam penggunaan air dan unsure hara sehingga akan mempengaruhi produksi tanaman (Hidayat, 2008 dalam Rahmawati, 2017).

Landasan teori dan permasalahan di atas, menjadi dasar bagi penulis dalam melakukan kajian tentang Optimalisasi Jarak Tanam Terhadap Pertumbuhan dan Produksi Bawang Merah (Allium ascalonicum, $L$ ) pada Musim Penghujan di Desa Torongrejo Kecamatan Junrejo Kota Batu.

Penelitian ini bertujuan untuk Mengetahui jarak tanam yang optimal terhadap pertumbuhan dan produksi bawang merah (Allium ascalonicum, L) pada musim penghujan di Desa Torongrejo.

\section{METODE PENELITIAN}

Kajian ini dilaksanakan dengan metode eksperimental, menggunakan Rancangan Acak Kelompok (RAK) sederhana. Adapun perlakuan dalam kajian adalah $\mathrm{J} 0=15 \times 15 \mathrm{cmJ} 1=20 \times 20 \mathrm{~cm}, \mathrm{~J} 2=$ $25 \times 25 \mathrm{~cm}$ dan $\mathrm{J} 3=30 \times 30 \mathrm{~cm}$. Setiap perlakuan akan diulang sebanyak 6 kali sehingga terdapat 24 satuan percobaan dengan luasan perplot $2 \mathrm{~m}^{2}$.

Penentuan sampel menggunakan teknik non destraktif dimana pengamatan dilakukan tanpa merusak tanaman sampel. Jumlah yang diamati pada masing-masing satuan percobaan (plot) adalah enam tanaman untuk setiap perlakuan, sehingga dikalidengan 6 ulangan dengan 24 satuan percobaan (plot) menghasilkan144 sampel tanaman.

Parameter yang diamati adalah tinggi tanaman, jumlah daun, bobot basah dan 
bobot kering, persentase serangan hama penyakit dan produksi dalam satuan ton/ha Analisis Data Hasilpengamatan yang diperolehditabulasikan kemudian dilakukan uji Analisiof Varians (Anova) dengan menggunakan program SPSS 22 pada taraf nyata 5\% dengan hipotesis antara lain:

Ho : Tidak terdapat pengaruh perlakuan jarak tanam terhadap pertumbuhan dan produksi bawang merah.

Ha : Terdapat pengaruh perlakuan jarak tanam terhadap pertumbuhan dan produksi bawang merah.

Kaidah Keputusan untuk hasil uji Anova pada SPSS 22 antara lain :

1. Jika nilai probabilitas ( $p$-value) yang tercantum dalam kolom Sig.> 0,05 maka Ho diterima

2. Jika nilai probabilitas ( $p$-value) yang tercantum dalam kolom Sig. $<0,05$ maka Ho ditolak
Apabila Ho ditolak, maka dilakukan uji lanjut DMRT (Duncan's Multiple Range Test) pada taraf 5\% dengan menggunakan program analisis SPSS 22.

\section{HASIL DAN PEMBAHASAN}

\section{Pengaruh Jarak Tanam terhadap TinggiTanaman Bawang Merah}

Hasil uji ANOVAmenunjukkan bahwa nilai probabilitas $(p$-value $)<0,05$ sehingga untuk parameter tinggi tanaman Ho ditolak yang artinya terdapat pengaruh yang nyata perlakuan jarak tanam terhadap tinggi tanaman mulai umur 14 hst sampai 49 hst. Karena Ho ditolak maka dilakukan uji lanjut menggunakan uji DMRT, hasil uji dapat dilihat pada table 1 .

Tabel 1. Pengaruh Jarak Tanam terhadap Tinggi Tanaman

\begin{tabular}{ccccccc}
\hline \multirow{2}{*}{ Perlakuan } & \multicolumn{7}{c}{ Pengamatan } \\
\cline { 2 - 7 } & $14 \mathrm{HST}$ & $21 \mathrm{HST}$ & $28 \mathrm{HST}$ & $35 \mathrm{HST}$ & $42 \mathrm{HST}$ & $49 \mathrm{HST}$ \\
\hline J0 & $23,68 \mathrm{a}$ & $25,71 \mathrm{a}$ & $30,79 \mathrm{a}$ & $34,02 \mathrm{a}$ & $33,58 \mathrm{a}$ & $32,09 \mathrm{a}$ \\
J1 & $22,60 \mathrm{a}$ & $25,17 \mathrm{a}$ & $29,89 \mathrm{a}$ & $33,08 \mathrm{a}$ & $33,47 \mathrm{a}$ & $31,57 \mathrm{a}$ \\
J2 & $18,86 \mathrm{~b}$ & $22,32 \mathrm{~b}$ & $24,60 \mathrm{~b}$ & $25,71 \mathrm{~b}$ & $26,05 \mathrm{~b}$ & $25,95 \mathrm{~b}$ \\
J3 & $15,09 \mathrm{c}$ & $18,14 \mathrm{c}$ & $20,56 \mathrm{c}$ & $24,97 \mathrm{~b}$ & $25,01 \mathrm{c}$ & $24,62 \mathrm{c}$ \\
\hline
\end{tabular}

Keterangan : Angka-angka yang diikuti huruf yang sama pada setiap kolom yang sama tidak berbeda nyata menurut uji lanjut DMRT pada taraf $5 \%$.

Hasil uji lanjut DMRT pada Tabel 1 menunjukkan bahwa tinggi tanaman bawang merah pada jarak tanam $15 \times 15 \mathrm{~cm}$ (J0) tidak berbeda nyata dengan tinggi tanaman bawang merah pada jarak tanam $20 \times 20 \mathrm{~cm}(\mathrm{~J} 1)$ dan menghasilkan tinggi tanaman yang lebih tinggi dibandingkan dengan jarak tanam $25 \times 25 \mathrm{~cm}(\mathrm{~J} 2)$ dan 30 x $30 \mathrm{~cm}(\mathrm{~J} 3)$. Sehingga untuk parameter tinggi tanaman, jarak tanam yang paling optimal adalah $15 \times 15 \mathrm{~cm}$ (J0) dan $20 \times 20$ cm (J1).

Berdasarkan hasil analisis tersebut, dapat diketahui bahwa jarak tanam $15 \times 15$ $\mathrm{cm}$ (J0) dan $20 \quad \mathrm{x} \quad 20 \mathrm{~cm} \quad$ (J1) akan meningkatkan pertambahan tinggi tanaman karena ruang tumbuh yang sangat sempit sehingga tanaman tumbuh memanjang ke 135 | Jurnal Agriekstensia Vol. 17 No. 2 Desember 2018 atas untuk mendapatkan sinar matahari atau dapat dikatakan terjadi etiolasi. Etiolasi merupakan pertumbuhan tumbuhan yang sangat cepat ditempat yang kekurangan sinar matahari, namun kondisi tanaman lemah, daunnya kecil serta kualitas tanaman rendah. Hal ini sesuai dengan penelitian Nursanti (2009), yang menyatakan semakin rapat tanaman maka pertumbuhan tinggi tanaman akan semakin cepat karena akan mencari sinar matahari yang lebih banyak. Jilani dan Ghaffor (2003) juga menyatakan bahwa kerapatan tanaman mempengaruhi panjang daun yang dalam kajian ini disebut tinggi tanaman. Jadi, dapat disimpulksn bahwa kerapatan $15 \times 15 \mathrm{~cm}$ (J0) dan $20 \mathrm{x}$ $20 \mathrm{~cm}$ (J1) mampu menghasilkan panjang 
daun tertinggi namun dengan kualitas tanamam yang rendah.

\section{Pengaruh Jarak Tanam terhadap Jumlah Daun}

Hasil uji ANOVA menunjukkan bahwa nilai probabilitas ( $p$-value) $<0,05$ sehingga untuk parameter jumlah daun Ho ditolak yang artinya terdapat pengaruh yang nyata perlakuan jarak tanam terhadap jumlah daun mulai umur 14 hst sampai 49 hst. Karena Ho ditolak maka dilakukan uji lanjut menggunakan uji DMRT (Duncan's Multiple Range Test) yang hasilnya disajikan pada Tabel 2.

Tabel 2. Pengaruh Jarak Tanam terhadap Jumlah Daun

\begin{tabular}{ccccccc}
\hline \multirow{2}{*}{ Perlakuan } & \multicolumn{6}{c}{ Pengamatan } \\
\cline { 2 - 7 } & $14 \mathrm{HST}$ & $21 \mathrm{HST}$ & $28 \mathrm{HST}$ & $35 \mathrm{HST}$ & $42 \mathrm{HST}$ & $49 \mathrm{HST}$ \\
\hline J0 & $14,22 \mathrm{~b}$ & $16,83 \mathrm{~b}$ & $21,11 \mathrm{~b}$ & $21,72 \mathrm{c}$ & $21,86 \mathrm{~b}$ & $21,86 \mathrm{~b}$ \\
J1 & $19,44 \mathrm{a}$ & $26,39 \mathrm{a}$ & $31,14 \mathrm{a}$ & $29,03 \mathrm{~b}$ & $26,06 \mathrm{~b}$ & $26,06 \mathrm{~b}$ \\
J2 & $20,81 \mathrm{a}$ & $27,89 \mathrm{a}$ & $33 \mathrm{a}$ & $31,61 \mathrm{ab}$ & $31,97 \mathrm{a}$ & $31,97 \mathrm{a}$ \\
J3 & $21,81 \mathrm{a}$ & $29,03 \mathrm{a}$ & $35,08 \mathrm{a}$ & $35,14 \mathrm{a}$ & $34 \mathrm{a}$ & $34 \mathrm{a}$ \\
\hline
\end{tabular}

Keterangan : Angka-angka yang diikuti huruf yang sama pada setiap kolom yang sama tidak berbeda nyata menurut uji lanjut DMRT pada taraf 5\%

Hasil uji lanjut DMRT pada Tabel 2 menunjukkan bahwa jarak tanam $30 \times 30$ $\mathrm{cm}$ (J3) tidak berbeda nyata dengan jarak tanam $25 \times 25 \mathrm{~cm}(\mathrm{~J} 2)$ dan $20 \times 20 \mathrm{~cm}(\mathrm{~J} 3)$ dan lebih tinggi dari jarak tanam $30 \times 30 \mathrm{~cm}$ (J3) pada umur 14 hst, 21 hst, 28 hst. Sehingga untuk parameter jumlah daun, jarak tanam yang paling optimal untuk digunakan adalah $30 \times 30 \mathrm{~cm}(\mathrm{~J} 3)$, diikuti $25 \times 25 \mathrm{~cm}(\mathrm{~J} 2)$ dan $20 \times 20 \mathrm{~cm}$ (J3).

Berdasarkan hasil pengamatan ini diketahui bahwa jumlah daun pada jarak tanam yang lebar $(30 \times 30 \mathrm{~cm})$ lebih banyak dibandingkan dengan jarak tanam yang sempit $(15 \times 15 \mathrm{~cm})$. Hal ini disebabkan karena pada jarak tanam 15 x $15 \mathrm{~cm}$ terdapat persaingan antar tanaman terhadap pemenuhan nutrisi, sinar matahari, kelembaban udara yang tinggi yang dikarenakan ruang gerak yang sempit. Hal ini diperkuat oleh Pambayun (2008), yang mengatakan bahwa jumlah daun dan jumlah cabang daun meningkat pada jarak tanam yang lebar sebab pada jarak yang lebar kompetensi antar tanaman lebih rendah sehingga setiap individu tanaman mempunyai ruang tumbuh yang lebih besar dan tajuk dapat berkembang dengan baik. Jan dkk. (2003), Akoun (2005), Wayan dkk. (2008), Ahmed dkk. (2010) dan Jilani dkk. (2010) dalam Yemane dkk. (2014), juga mengatakan bahwa jarak antar tanaman yang terlalu rapat mengakibatkan penurunan jumlah daun karena kekurangan gizi, mineral, kelembaban udara yang tinggi, dan kurangnya ruang tumbuh.

\section{Pengaruh Jarak tanam Terhadap Bobot Basah dan Bobot Kering Umbi Bawang Merah}

Hasil uji ANOVA menunjukkan bahwa nilai probabilitas ( $p$-value $)<0,05$ sehingga untuk berat basah dan berat kering bawang merah dengan nilai penyusutan sebesar $23 \%$, Ho ditolak yang artinya terdapat pengaruh yang nyata perlakuan jarak tanam terhadap berat basah dan berat kering. Karena Ho ditolak maka dilakukan uji lanjut menggunakan uji DMRT (Duncan's Multiple Range Test) yang hasilnya disajikan pada Tabel 3.

\section{Tabel 3. Pengaruh Jarak Tanam terhadap Bobot Basah dan Bobot Kering Per Petak}

$\begin{array}{ccc}\text { Perlakuan } & \text { Berat Basah (gram) } & \text { Berat Kering (gram) } \\ \text { J0 } & 1256,83 \mathrm{~b} & 1021,83 \mathrm{~b}\end{array}$


Optimalisasi Jarak Tanam terhadap Pertumbuhan (Yustina E. W. Lea, Abdul Farid, dan Arum Pratiwi)

$\begin{array}{lll}\mathrm{J} 1 & 1462,17 \mathrm{a} & 1241,17 \mathrm{a} \\ \mathrm{J} 2 & 854,50 \mathrm{c} & 644,50 \mathrm{c} \\ \mathrm{J} 3 & 718,50 \mathrm{~d} & 508,50 \mathrm{~d}\end{array}$

Keterangan : Angka-angka yang diikuti hurufyang sama pada setiap kolom yang sama tidak berbeda nyata menurut uji lanjut DMRT pada taraf 5\%.

Tabel 3 menunjukkan bahwa setiap perlakuan jarak tanam memberikan pengaruh yang berbeda nyata terhadap bobot bawang merah baik bobot kering maupun bobot basah. Bobot kering dan bobot basah tertinggi terdapat pada perlakuan J1 dengan jarak tanam $20 \times 20$ $\mathrm{cm}$ dikarenakan jarak tanam $20 \times 20 \mathrm{~cm}$ merupakan jarak tanam yang optimal yakni tidak terlalu lebar dan tidak terlalu rapat, sehingga terjadi keseimbangan antara tinggi tanaman dan jumlah daun yang berpengaruh pada bobot umbi.

Jarak tanam 20 × $20 \mathrm{~cm}$ menghasilkan umbi dengan bobot dan ukuran yang sedang sehinga meskipun populasi tanaman tidak sebanyak populasi tanaman pada jarak tanam 15 x $15 \mathrm{~cm}$ namun dapat menghasilkan bobot keseluruhan yang lebih berat. Sedangkan untuk jarak tanam yang lebih lebar $(25 \times 25 \mathrm{~cm}$ dan $30 \times 30 \mathrm{~cm})$ meskipun menghasilkan umbi dengan ukuran yang lebih besar namun bobot umbi per plotnya rendah, dikarenkaan populasi tanaman sedikit. Hal ini sesuai dengan hasil penelitian dari Yulisma (2011) mengatakan bahwa jarak tanam yang terlalu rapat akan menghambat pertumbuhan tanaman, tetapi jika terlalu jarang akan mengurangi populasi per satuan luas. Oleh karena itu, diperlukan strategi pengelolaan lahan, antara lain dengan menciptakan kondisi lingkungan tumbuh yang sesuai untuk mencapai hasil maksimal (Rambitan, 2005)

\section{PengaruhJarakTanamterhadap Prosentase Serangan Hama}

Hama yang menyerang tanaman bawang merah adalah hama ulat bawang (grayak). Serangan ditandai dengan adanya bercak berwarnah putih transparan karena ulat melubangi daun bagian ujung, masuk dan memakan daging bagian dalam, akibatnya daun terkulai dan kering. Prosentase serangan hama mulai dihitung pada saat umur tanaman 28 HST, sampai 49 HST, karena pada awal pertumbuhan belum ada gejala serangam hama pada setiap pengamatan. Data persentase serangan hama dapat dilihat melalui diagram pada Gambar 1.

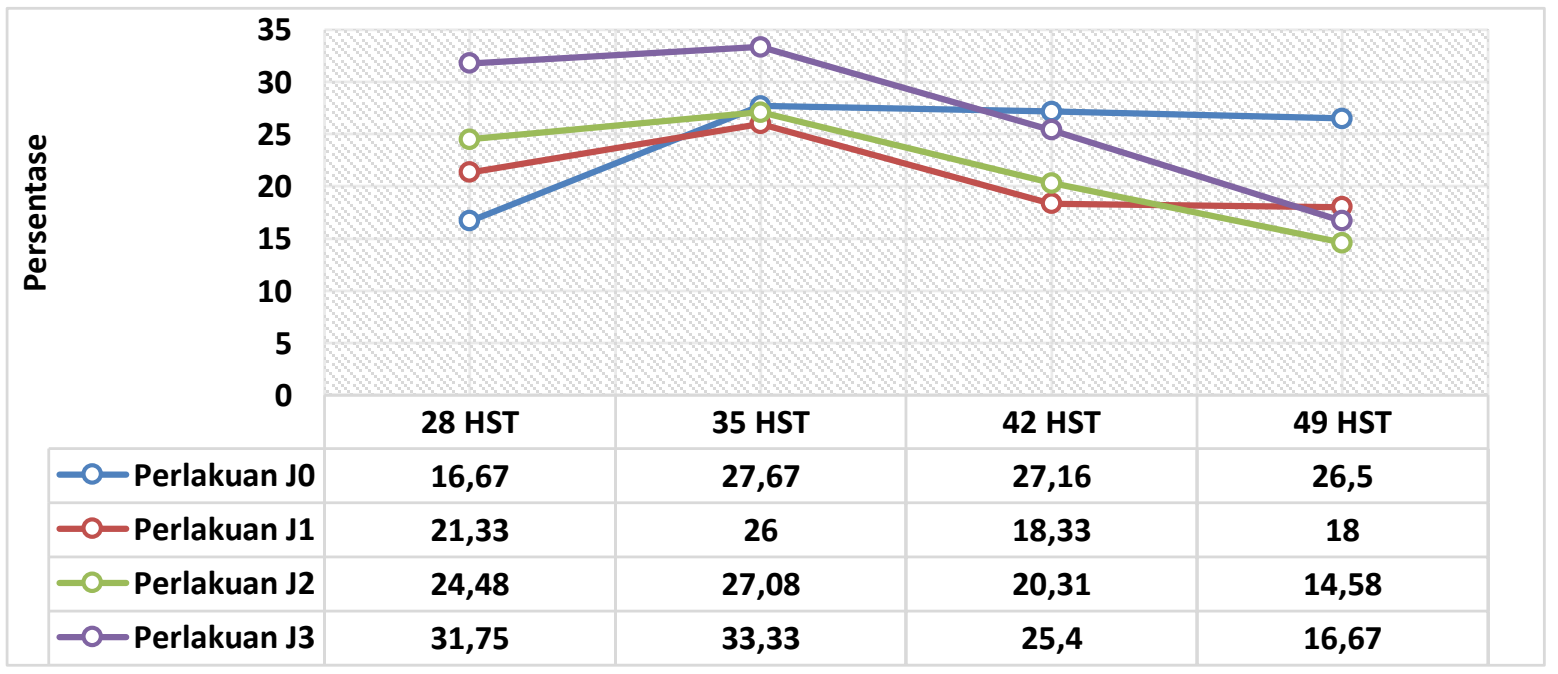

Gambar1. Pengaruh Jarak Tanam terhadap Persentase Hama 
Berdasarkan Gambar 1 diketahui bahwa jarak tanam berpengaruh dalam menekan perkembangan hama ulat bawang (grayak). Dari empat perlakuan, jarak tanam yang paling optimal untuk menekan perkembangan hama ulat bawang adalah jarak tanam $30 \times 30 \mathrm{~cm}$ (J3) diikuti dengan jarak tanam $25 \times 25 \mathrm{~cm}(\mathrm{~J} 2), 20 \times 20 \mathrm{~cm}$ (J1) terlihat berdasarkan gambar 1 bahwa pada 35 hst peningkatan serangan hama tidak terlalu tinggi sebesar $1,58 \%$ dan kemudian mengalami penurunan yang signifikan pada 42 hst dan 49 hst sebesar $7,93 \%$ dan $8,73 \%$. Sedangkan jarak tanam $15 \times 15 \mathrm{~cm}(\mathrm{~J} 0)$, mengalami peningkatan serangan tertinggi pada 35 hst sebesar $11 \%$ dan kemudian tidak terjadi penurunan pada 42 hst dan 49 hst. Hal ini disebabkan karena pada jarak tanam $30 \times 30 \mathrm{~cm}(\mathrm{~J} 3), 25 \mathrm{~cm}$ x $25 \mathrm{~cm}(\mathrm{~J} 2)$ dan $20 \times 20 \mathrm{~cm}$ (J1) terdapat ruang gerak yang lebih lebar sehingga hama menjadi sulit untuk berpindah dari tanaman yang satu ke tanaman yang lain serta kondisi tanah tidak terlalu lembab karena paparan sinar matahari yang cukup sehingga mengusik keberadaan hama dan hama akan berpindah ke tempat yang lain. Jadi dapat disimpulkan bahwa jarak tanam $30 \times 30 \mathrm{~cm}$ (J3) diikuti $25 \times 25 \mathrm{~cm}(\mathrm{~J} 2)$ dan 20 x $20 \mathrm{~cm}$ (J1) lebih efektif dalam menekan perkembangan hama.
Hal ini didukung dengan penelitian yang dilakukan oleh Hill (2003) yang menyatakan bahwa jarak tanam yang lebar dapat menambah atau meningkatkan efektifitas musuh alami, serta merusak ketentraman hama melalui penyinaran matahari yang maksimal, sehingga hama dapat hilang atau pun berpindah ke lain tempat.

\section{Pengaruh Jarak Tanam terhadap Prosentase Serangan Penyakit}

Penyakit yang menyerang tanaman bawang merah adalah busuk daun atau antraknos. Serangan awal ditandai dengan terlihatnya bercak putih pada daun, selanjutnya terbentuk lekukan ke dalam, berlubang dan patah, karena daun terkulai tepat pada bercak. Infeksi lanjutan membentuk spora dan mulai menyebar dipermukaan tanah dan mulai menginfeksi tanaman lain karena curah hujan yang tinggi.

Prosentase serangan penyakit mulai dihitung pada saat umur tanaman $21 \mathrm{hst}$ sampai 49 hst karena pada awal pertumbuhan belum ada gejala serangam penyakit pada setiap pengamatan. Untuk data persentase serangan penyakit dapat dilihat melalui diagram pada Gambar 2.

\begin{tabular}{|c|c|c|c|c|c|c|}
\hline & \multirow{7}{*}{$\begin{array}{l}30 \\
25 \\
20 \\
15 \\
10\end{array}$} & & & & \multirow{3}{*}{\multicolumn{2}{|c|}{$\begin{array}{l}0 \\
0 \\
0\end{array}-0$}} \\
\hline & & & & & & \\
\hline & & & & & & \\
\hline & & & & & & \\
\hline & & & & & & \\
\hline & & & \multirow[b]{2}{*}{28 HST } & \multirow[b]{2}{*}{35 HST } & \multirow[b]{2}{*}{42 HST } & \multirow[b]{2}{*}{49 HST } \\
\hline & & 21 HST & & & & \\
\hline & - Perlakuan Jo & 11,11 & 17,52 & 22,65 & 30,77 & 32,69 \\
\hline & -O-Perlakuan J1 & 13 & 17,33 & 20,67 & 22,33 & 22,67 \\
\hline & -O-Perlakuan J2 & 15,63 & 18,23 & 19,27 & 19,79 & 20,83 \\
\hline & -O-Perlakuan J3 & 23,81 & 24,6 & 25,4 & 26,19 & 26,98 \\
\hline
\end{tabular}

Gambar 2. Pengaruh Jarak Tanam terhadap Persentase Serangan Penyakit

Berdasarkan Gambar 2 dapat dilihat bahwajarak tanam berpengaruh dalam menekan perkembangan penyakit layu. Dari empat perlakuan, jarak tanam yang paling optimal untuk menekan perkembangan penyakit layu adalah jarak tanam 30 x 30 $\mathrm{cm}$ (J3) diikuti dengan jarak tanam $25 \times 25$ $\mathrm{cm}(\mathrm{J} 2)$, dan $20 \times 20 \mathrm{~cm}$ (J1) sedangkan 
jarak tanam yang terlalu rapat yaitu $15 \times 15$ $\mathrm{cm}$ (J0) dapat memicu muncul dan berkembangnya persentase serangan penyakit.

Pada jarak tanam paling rapat $15 \times 15$ $\mathrm{cm}$ (J0), terlihat peningkatan prosentase serangan tertinggi pada 42 hst sebesar $8,12 \%$ dan terus meningkat sampai 49 hst. Peningkatan tersebut dipengaruhi oleh kelembaban tinggi dan populasi tanaman yang banyak sehingga perkembangbiakan penyakit menjadi lebih cepat. Dugaan ini diperkuat oleh hasil penelitian dari Asmaliyah dan Tati Rostiwati (2012) yang mengatakan bahwa Jarak tanam yang rapat dan kepadatan populasi yang lebih besar menyebabkan kelembaban di sekitar tanaman meningkat. Meningkatnya kelembaban tersebut dapat menyebabkan tanaman menjadi peka terhadap serangan penyakit dan menstimulir berkembangannya patogen serta menciptakan kondisi yang kurang sesuai dengan persyaratan tumbuh tanaman seperti ketersediaan unsur hara dan cahaya matahari.

\section{Pengaruh Jarak Tanam terhadap Produksi Bawang Merah \\ Data produksi bawang merah} diperoleh dengan mengkonversikan bobot kering umbi bawang merah dalam satu plot perlakuan keadalam satuan ton/hektar.

Tabel 4. Produksi Bawang Merah dalam Ton/Ha pada Jarak Tanam yang Berbeda

\begin{tabular}{cc} 
Perlakuan & Produksi ton/ha \\
\hline J0 & $5,1 \mathrm{~b}$ \\
J1 & $6,2 \mathrm{a}$ \\
J2 & $3,2 \mathrm{c}$ \\
J3 & $2,5 \mathrm{~d}$ \\
\hline
\end{tabular}

Berdasarkan Tabel 12 diketahui bahwa produksi bawang merah tertinggi pada perlakuan $\mathrm{J} 1$ atau 20 x $20 \mathrm{~cm}$. Sehingga dapat disimpulkan bahwa jarak tanam yang optimal yang sebaiknya diterapkan pada budidaya bawang merah pada musim hujan untuk Desa Torongrejo adalah 20 x $20 \mathrm{~cm}$. Hal ini membuktikan bahwa jarak tanam yang optimal adalah jarak tanam yang tidak terlalu rapat dan juga tidak terlalu lebar.

Jika dilihat dari perlakuan jarak tanam yang terlalu rapat yang dalam kajian ini adalah J0 (15 x $15 \mathrm{~cm})$, hanya unggul pada parameter tinggi tanaman dan jumlah populasi tetapi rendah pada para meter jumlah daun, bobot umbi dan dalam menekan serangan hama penyakit. Sementara untuk jarak tanam yang terlalu lebar J2 (25 X $25 \mathrm{~cm})$ dan J3 $(30 \times 30 \mathrm{~cm})$ hanya unggul pada para meter jumlah daun dan dalam menekan serangan hama penyakit, tetapi rendah pada parameter bobot umbi dan produksi. Pendapat ini diperkuat dengan hasil penelitian dari Yulisma (2011), yang menyatakan bahwa jarak tanam yang terlalu rapat akan menghambat pertumbuhan tanaman karena tingginya serang hama penyakit serta kekurangan unsur hara dan cahaya matahari, tetapi jika terlalu jarang akan mengurangi jumlah populasi persatuan luas. Pengaturan jarak tanam yang sesuai dengan jenis tanaman akan berpengaruh baik terhadap pertumbuhan dan hasil tanaman (Cahyono, 2002 dalam Asmiliyah dan Tati Rostiwati, 2012).

\section{KESIMPULAN}

Jarak tanam yang paling optimal untuk meningkatkan pertumbuhan dan hasil bawang merah pada musim penghujan di Desa Torogrejo Kecamatan Junrejo Kota Batu adalah $20 \times 20 \mathrm{~cm}$ dengan produksi sebesar 6,2 ton/Ha. 


\section{DAFTAR PUSTAKA}

Asmaliyah dan Tati Rostiwati. 2012. Pengaruh Pengaturan Jarak Tanam terhadap Perkembangan Serangan Hama dan Penyakit Pulai Darat. Palembang: Jurnal Penelitian Hutan Tanaman.

BALITSA, 2013. Teknologi Bawang Merah Off-Season: Strategi dan Implementasi Budidaya. Bandung: Balai Penelitian Tanaman Sayuran.

Hill, S.B. 2003. Cultural Methods of Pest, Primarily Insect, Control. MeGill University.

Nursanti, R. 2009. Pengaruh Umur Bibit dan Jarak Tanam terhadap Pertumbuhan dan Produktivitas Tanaman Buru Hotong. Bogor: IPB.
Pambayun, R. 2008. Pengaruh Jarak Tanam terhadap Produksi Beberapa Sayuran Indigenus. Bogor: IPB.

Pusat Data dan Sistem Informasi Pertanian. 2015. Outlook Bawang Merah. Jakarta: Kementrian Pertanian.

Rahmawati. 2017. Pengaruh Beberapa Jarak Tanam Terhadap Pertumbuhan dan Hasil Tanaman Kacang Tanah Varietas Kelinci (Arachis hypogeae L.). Sumatra Barat: Jurnal Pertanian Faperta UMSB.

Yulisma. 2011. Pertumbuhan dan Hasil Beberapa Varietas Jagung pada Berbagai Jarak Tanam. Jakarta: Penelitian Pertanian Tanaman Pangan. 